\title{
Pengaruh Yoga Pernapasan (Pranayama) Terhadap Kecemasan Keluarga Pasien Kritis di Ruang ICU
}

\author{
Lukmanulhakim $^{\left(1^{*}\right)}$, Desti Agustina ${ }^{(2)}$ \\ ${ }^{1}$ Sekolah Tinggi Ilmu Kesehatan Faletehan Serang \\ ${ }^{2}$ Sekolah Tinggi Ilmu Kesehatan Faletehan Serang \\ ${ }^{\left({ }^{*}\right)}$ lukmanulhakimshodrudin@yahoo.com; ${ }^{(2)}$ agustinadesti@gmail.com
}

\section{ARTICLE INFO}

Article history:

Received 12 April 2018

Revised 4 May 2018

Accepted 10 May 2018

\section{Keyword:}

Intensive Care Unit

Anxiety

Patient's Family

Respiratory Yoga (Pranayama)

(*) corresponding author

DOI: http://dx.doi.org/10.30604/jika.v3i1.91

\section{A B S T R A C T}

Intensive care unit is one of the most challenging places that can cause emotional disorder, if one family member is sick then the emotional ties other family members will arise interpreted in the form of feel each other. Yoga Pranayama is one of the Complementary and Alternative Therapies (CATs) group which is an intervention that can be given by nurses with the aim of reducing the discomfort caused by anxiety. The purpose of research is to determine the effect of respiratory yoga (pranayama) interventions to the critical patient's family anxiety in ICU RSUD dr. Dradjat Prawiranegara. The study design was quasi experiments pre-test andpost-test one-group. Research instrument was instrument ZRAS (Zung Rating Anxiety Scale). The sample in this research of 25 people. The sampling in this research using nonprobability sampling with purposive sampling technique. From the 25 respondents shown there respiratory yoga (pranayama) affected on critical patient's family anxiety with p value $0.000(<$ 0.05). The results suggest this study can be recommended as a medium or intervention to the families of critical patients in the fulfillment of nursing care holistically.
\end{abstract}

Copyright @ 2018 , Jurnal Aisyah: Jurnal Ilmu Kesehatan. All rights reserved.

\section{PENDAHULUAN}

Pelayanan keperawatan kritis merupakan suatu pelayanan dalam lingkup Rumah Sakit yang menyediakan fasilitas yang khusus baik dari peralatan ataupun tenaga medis yang trampil dan terlatih (Evans, 2015). Core Standards for Intensive Care Units (2013), menjelaskan bahwa setiap pasien yang dirawat di pelayanan keperawatan kritis atau ruang perawatan intensif dipandang sebagai individu yang unik yang harus menerima kenyamanan, privasi lingkungan, serta mendapatkan perawatan dengan teknologi atau peralatan yang canggih. Dalam melakukan perawatan pasien kritis harus bekerja sama dengan anggota tim perawatan lainnya agar tercapai perawatan yang holistik.

Pasien yang dirawat di ruang perawatan intensif akan merasa mendapat ancaman 
kehidupan dan merasa akan tiba kematian, hal ini menyebabkan adanya gangguan psikologis pada pasien. Perubahan yang terjadi tidak hanya dirasakan oleh pasien yang dirawat diruangan ICU saja tetapi juga memiliki dampak perubahan pada kondisi keluarga Keluarga memasuki situasi yang tidak terencana dengan hasil yang tidak terduga dan seringkali dipaksa untuk menjalani peran pengambil keputusan.

Pengkajian keperawatan yang holistik harus disertakan dalam perumusan diagnosa keperawatan. Standar yang disusun American Association of Critical-Care Nurses menekankan dan mendukung pentingnya pengkajian keluarga dan keterlibatan keluarga dalam asuhan keperawatan kritis. Pada kondisi ini dukungan keluarga menjadi kepentingan utama. Pengaruh keluarga dalam keikutsertaannya menentukan kebijakan dan keputusan dalam penggunaan layanan keperawatan sehingga hubungan dengan keluarga menjadi penting. Keluarga sangatlah berperan dalam proses penyembuhan dan pemulihan pasien (Morton, Fontaine, Hudak, \& Gallo, 2011).

Kecemasan (ansietas) ini dapat diatasi dengan beberapa cara, antara lain terapi farmakologi dan terapi non farmakologi. Terapi farmakologi seperti obat anti cemas (anxiolytic) dapat membantu menurunkan cemas tetapi memiliki efek ketergantungan, sedangkan terapi non farmakologi seperti terapi relaksasi, meditasi hypnosis dan yoga yang merupakan kelompok Complementary and Alternatives Therapies (CATs) adalah intervensi yang dapat dilakukan oleh perawat dengan tujuan menjaga kesehatan dan kesejahteraan (Solehati dan kosasih, 2015). Nasional Clinical Excellence (NICE) merekomendasikan orang dengan gangguan kecemasan untuk melakukan terapi yoga, karena terapi non farmakologi ini memiliki efek samping yang minimal jika dipraktekan (Kirkwood, G., Rampes, H., Tuffrey, V., Richardson, J., Pilkington, K. 2005).
Yoga pernapasan (pranayama) merupakan latihan pernapasan dengan tehnik bernapas menggunakan otot-otot diafragma, bernapas dengan cara perlahan dan dalam, sehingga dada dapat mengembang penuh dan memungkinkan abdomen terangkat perlahan (Sani, 2012). Sindhu (2014), mengemukakan bahwa dengan menguasai tehnik pernapasan sama halnya dengan menguasai emosi dan pikiran, melalui napas lembut dan teratur pikiran akan menjadi lebih tenang dan tubuh menjadi lebih rileks.

Uraian diatas telah dibuktikan pada penelitian hampir serupa oleh Winarti (2014), dalam penelitiannya mengenai perbedaan tingkat stress pada lansia sebelum dan setelah diberikan senam yoga sebanyak 3 kali pertemuan di Unit Rehabilitas Sosial Wening Wardoyo Ungaran, mengidentifikasi bahwa adanya perbedaan rata rata tingkat stress pada lansia sebelum dan sesudah diberikan yoga dengan nilai mean sebesar 8.61 dengan standar deviasi sebesar 0.751. Penelitian lainnya yang mengidentifikasi manfaat yoga dilakukan oleh Oktaviana (2014), dalam penelitiannya mengenai pengaruh terapi yoga terhadap stress pada penderita kanker stadium III dan IV di rumah sakit Muhammadiyah Palembang didapatkan hasil bahwa terjadinya penurunan skor stres setelah diberikan terapi yoga dengan $p$ value sebesar 0.000 .

Hasil studi pendahuluan yang dilakukan di ruang Intensive Care Unit (ICU) RSUD dr. Dradjat Prawiranegara, dari hasil wawancara 5 orang keluarga pasien kritis, dengan lamanya menunggu anggota keluarga dalam waktu yang bervariasi yaitu dari rentang 4-6 hari, 4 orang merasakan was-was terhadap kondisi keluarga yang sedang dirawat di ruang ICU, mengalami gangguan tidur karena merasa khawatir akan kondisi pasien yang dirawat di ruang ICU, terkadang merasa sedih dengan kondisi pasien saat ini karena merasa takut akan kehilangan keluarga yang dirawat di 
ruang ICU. Sedangkan 1 orang dari keluarga pasien menyatakan tidak merasakan khawatir dengan kondisi keluarganya yang dirawat karena pasien sudah mulai membaik dan keluarga sudah mulai beradaptasi dengan kondisi pasien. Melihat uraian diatas maka penelitian ini bertujuan untuk melihat pengaruh yoga pernapasan (pranayama) terhadap kecemasan keluarga pasien kritis diruang ICU RSUD dr. Dradjat Prawiranegara Serang.

\section{METODE}

Jenis penelitian penelitian yang digunakan dalam penelitian ini adalah Quasi eksperiment dengan pre test dan post test one-group design without control, yang bertujuan untuk mengetahui perbedaan rerata kecemasan keluarga pasien kritis sebelum dan sesudah diberikannya intervensi yoga pernapasan (pranayama) di ruang ICU RSUD dr. Dradjat Prawiranegara Serang Banten.

Populasi dalam penelitian ini adalah semua keluarga pasien di Ruang ICU RSUD dr.Dradjat Prawiranegara Serang Banten. Pengambilan sampel dalam penelitian ini menggunakan jenis nonprobability sampling dengan tehnik purposive sampling yang merupakan suatu teknik pengambilan sampel dengan cara memilih sampel diantara populasi yang sesuai dengan yang dikriteria peneliti, sehingga sampel tersebut dapat mewakili populasi. Perhitungan besar sampel dalam penelitian ini menggunakan estimasi besaran sampel untuk penelitian yang bertujuan menguji hipotesis beda dua mean kelompok berpasangan (Dahlan, 2016), dan hasil perhitungan diperoleh sebanyak 25 sampel penelitian. Penelitian ini dilaksanakan di Ruang ICU RSUD dr. Dradjat Prawiranegara Serang Banten Tahun 2017 pada $16 \mathrm{Mei}$ - 31 Mei 2017.

Alat pengumpulan data yang digunakan dalam penelitian ini untuk megukur tingkat kecemasan menggunakan Zung Self-Rating
Anxiety Scale (ZRAS) yang terdiri dari 20 pertanyaan, dimana setiap pertanyaan dinilai dengan skala likert dengan rentang penialain 1-4. Rentang keseluruhan penilaian skor antara 20-80. Tingkat validitas dan realibilitas skala kecemasan menurut Zung yang telah dimodifikasi oleh Rachmaniah (2012) pada penelitian sebelumnya dengan judul Pengaruh Psikoedukasi terhadap Kecemasan dan Koping Orang Tua dalam Merawat Anak dengan Thalasemia Mayor di RSU Kabupaten Tangerang Banten, diperoleh nilai untuk kecemasan terendah 0,688 dan tertinggi 0,927 dengan nilai Alpha Chronbach 0,970. Instrumen ini diberikan pada saat pre-test dan post-tes.

Sedangkan intervensi yoga dilakukan dengan mendatangkan praktisi yoga yang telah tersertifikasi oleh metta mom's care Intervensi yoga pernapasan diberikan selama 4 kali pertemuan. Setiap intervensi dengan durasi 10 -15 menit (Sani, 2012). Bentuk Controling peneliti, selanjutnya peneliti membuat Booklet sebagai panduan dalam melakukan intervensi yoga pranayama serta membuat group dengan mengoptimalkan penggunaan aplikasi media smartphone.

Hasil uji normalitas berdasarkan nilai skewness dibagi standar error berada pada rentang -2 sampai dengan +2 , yaitu $-2,090$ (Pre Test) dan -0,297 (Post Test), sehingga dapat disimpulkan bahwa data berdistribusi normal. Uji statistik yang digunakan dalam penelitian ini menggunakan uji $t$-dependent (Paired t-test).

\section{HASIL DAN PEMBAHASAN}

Analisis univariat dalam penelitian ini digunakan untuk memberikan gambaran kecemasan dan karakteristik keluarga pasien kritis di ruang ICU RSUD dr. Dradjat Prawiranegara Serang Banten. 
Tabel 1. Distribusi Karakteristik dan Kecemasan Responden di Ruang ICU

\begin{tabular}{|c|c|c|c|c|}
\hline \multirow{2}{*}{ Variabel } & \multicolumn{2}{|c|}{ Sebelum } & \multicolumn{2}{|c|}{ Sesudah } \\
\hline & $\mathbf{F}$ & $\%$ & $\mathbf{F}$ & $\%$ \\
\hline \multicolumn{5}{|l|}{ Kecemasan } \\
\hline Mean & 42.80 & & 32.48 & \\
\hline Standar Deviasi & 5.228 & & 3.255 & \\
\hline Standar Eror & 1.046 & & 0.651 & \\
\hline $95 \%$ CI (Min - Maks) & $40.6-44.9$ & & $31.1-33.8$ & \\
\hline \multicolumn{5}{|l|}{ Usia } \\
\hline Dewasa awal (18 - 40 Tahun) & 20 & 80.0 & & \\
\hline Dewasa madya ( $40-60$ Tahun) & 5 & 20.0 & & \\
\hline \multicolumn{5}{|l|}{ Jenis kelamin } \\
\hline Laki - laki & 4 & 16.0 & & \\
\hline Perempuan & 21 & 84.0 & & \\
\hline \multicolumn{5}{|l|}{ Pendidikan } \\
\hline Tinggi ( $\geq$ SMA) & 16 & 64.0 & & \\
\hline Rendah ( $\leq$ SMP $)$ & 9 & 36.0 & & \\
\hline \multicolumn{5}{|l|}{ Bekerja } \\
\hline Bekerja & 15 & 60.0 & & \\
\hline Tidak bekerja & 10 & 40.0 & & \\
\hline \multicolumn{5}{|l|}{ Penghasilan keluarga } \\
\hline Diatas UMR & 15 & 60.0 & & \\
\hline Dibawah UMR & 10 & 40.0 & & \\
\hline
\end{tabular}

Tabel 1 menunjukkan bahwa responden terbanyak dengan kategori usia dewasa awal yaitu sebanyak 20 responden dalam rentang usia 18 - 40 Tahun, dengan jenis kelamin perempuan sebanyak 21 responden (84.0 persen) dan yang berpendidikan tinggi sebanyak 16 responden (64 persen), sisanya berpendidikan rendah. responden sebagian besar bekerja yaitu sebanyak 15 responden (60 persen), Jenis pekerjaan responden secara umum adalah buruh pabrik, PNS, wirausaha, wiraswasta, dan pembantu rumah tangga. penghasilan keluarga sebagian berada dibawah upah minimum regional (UMR) yaitu sebanyak
13 responden (52 persen), dan 12 responden (48 persen). berada diatas upah minimum regional (UMR) dan rata - rata kecemasan sebelum diberikan yoga pernapasan (pranayama) adalah 42.80 . Adapun setelah diberikan yoga pernapasan (pranayama) rata-rata kecemasan keluarga pasien kritis adalah 32.48 .

Analisis bivariat digunakan untuk mengetahui perbedaan kecemasan sebelum dan sesudah diberikan intervensi dan untuk mengetahui hubungan antara karakteristik keluarga pasien kritis dengan tingkat kecemasannya.

Tabel 2. Selisih Rata-Rata Kecemasan Keluarga Pasien Kritis Sebelum dan Setelah Diberikan Yoga Pernapasan (Pranayama) di ruang ICU.

\begin{tabular}{cccccc}
\hline Variabel & Mean & SD & SE & p value & N \\
\hline $\begin{array}{c}\text { Kecemasan } \\
\text { Pre test }- \text { Post test }\end{array}$ & 10.320 & 3.794 & 0.759 & 0.001 & 25
\end{tabular}

Berdasarkan tabel 2 dapat dijelaskan mengenai selisih rata-rata kecemasan keluarga pasien kritis di ruang ICU sebelum dan setelah diberikan yoga pernapasan (pranayama) adalah 10.320 dengan standar deviasi 3.794 dan standar eror 0.759. Hasil 
uji statistik diperoleh p value sebesar 0.000 , hal ini menunjukan bahwa korelasi antara dua rata - rata kecemasan sebelum dan setelah diberikan yoga pernapasan (pranayama) adalah kuat dan signifikan.

Tabel 3 Hubungan Usia, Jenis Kelamin, Tingkat Pendidikan, Status Pekerjaan dan Penghasilan Keluarga Dengan Kecemasan Keluarga Pasien Kritis di Ruang ICU

\begin{tabular}{|c|c|c|c|c|c|c|c|}
\hline \multirow{3}{*}{ Variabel } & \multicolumn{4}{|c|}{ Kecemasan } & \multirow{3}{*}{ Jumlah } & \multirow{3}{*}{ p value } & \multirow{3}{*}{$\begin{array}{c}\text { OR } \\
(95 \% \mathrm{CI})\end{array}$} \\
\hline & \multicolumn{2}{|c|}{$\begin{array}{c}\text { Kecemasan } \\
\text { Ringan }\end{array}$} & \multicolumn{2}{|c|}{$\begin{array}{c}\text { Kecemasan } \\
\text { Sedang }\end{array}$} & & & \\
\hline & $\mathrm{F}$ & $\%$ & $\mathrm{~F}$ & $\%$ & & & \\
\hline \multicolumn{8}{|l|}{ Usia } \\
\hline Dewasa Awal (18-40 Tahun) & 11 & 73.3 & 9 & 90 & 20 & 0.610 & 0.306 \\
\hline Dewasa Madya (40 - 60 Tahun) & 4 & 26.7 & 1 & 10 & 5 & & \\
\hline \multicolumn{8}{|l|}{ Jenis Kelamin } \\
\hline Laki - Laki & 2 & 50 & 2 & 50 & 4 & 1.000 & 0.615 \\
\hline Perempuan & 13 & 61.9 & 8 & 38.1 & 21 & & \\
\hline \multicolumn{8}{|l|}{ Tingkat Pendidikan } \\
\hline Tinggi ( $\geq$ SMA) & 14 & 93.3 & 2 & 20 & 16 & 0.001 & 56.000 \\
\hline Rendah ( $\leq$ SMP $)$ & 1 & 6.7 & 8 & 80 & 9 & & \\
\hline \multicolumn{8}{|l|}{ Status Pekerjaan } \\
\hline Bekerja & 12 & 80 & 3 & 30 & 15 & 0.037 & 9.333 \\
\hline Tidak Bekerja & 3 & 20 & 7 & 70 & 10 & & \\
\hline \multicolumn{8}{|l|}{ Penghasilan keluarga } \\
\hline Diatas UMR & 12 & 80 & 3 & 30 & 15 & 0.037 & 9.333 \\
\hline Dibawah UMR & 3 & 20 & 7 & 70 & 10 & & \\
\hline
\end{tabular}

Hasil penghitungan pada tabel 3 menunjukkan bahwa responden yang mengalami kecemasan ringan terbanyak adalah usia dewasa awal yaitu sebanyak 11 (73.3 persen) responden, sedangkan yang mengalami kecemasan sedang terbanyak adalah usia dewasa awal juga yaitu sebanyak 9 (90 persen) responden. Hasil uji statistik menunjukan p Value 0.610, sehingga dapat disimpulkan bahwa tidak terdapat hubungan antara usia dengan kecemasan yang dialami keluarga pasien kritis di ruang ICU RSUD dr. Dradjat Prawiranegara Serang banten. Begitupun dengan hasil analisis hubungan antara jenis kelamin dengan kecemasan, didapatkan data bahwa sebesar 61.9 persen responden dengan jenis kelamin perempuan mengalami kecemasan ringan sedangkan responden laki-laki didapatkan sebesar 50.0 persen dengan kecemasan ringan. Hasil Uji statistik didapatkan nilai $\mathrm{p}$ sebesar 1.000. sehingga dapat disimpulkan bahwa tidak terdapat hubungan antara jenis kelamin dengan kecemasan yang dialami keluarga pasien kritis di ruang ICU RSUD dr. Dradjat Prawiranegara Serang Banten.

Berdasarkan karakteristik pendidikan, responden yang mengalami kecemasan ringan terbanyak adalah responden yang berpendidikan tinggi ( $\geq$ SMA) yaitu sebanyak 14 (93.3 persen) responden. Sedangkan yang mengalami kecemasan sedang terbanyak adalah responden yang berpendidikan rendah $(\leq \mathrm{SMP})$ yaitu sebanyak 8 (80 persen) responden. Hasil uji statistik menunjukan p Value 0.001, sehingga dapat disimpulkan bahwa terdapat hubungan antara tingkat pendidikan dengan kecemasan yang dialami keluarga pasien kritis di ruang ICU RSUD dr. Dradjat Prawiranegara Serang Banten.

Berdasarkan status pekerjaan dan jumlah penghasilan, responden yang memiliki kecemasan ringan terbanyak adalah 
responden yang bekerja dan berpenghasilan diatas UMR, sedangkan responden yang memiliki kecemasan sedang terbanyak adalah responden yang tidak bekerja dan berpenghasilan dibawah UMR yaitu sebanyak 7 (70 persen) responden. Hasil uji statistik menunjukan p Value 0.037, sehingga dapat disimpulkan bahwa terdapat hubungan antara status pekerjaan dan penghasilan keluarga dengan kecemasan yang dialami keluarga pasien kritis di ruang ICU RSUD dr. Dradjat Prawiranegara Serang Banten.

\section{Gambaran Kecemasan Keluarga Pasien Kritis di ruang ICU}

Hasil penelitian menunjukan bahwa dari 25 responden rata-rata kecemasan keluarga pasien kritis di ruang ICU RSUD dr. Dradjat Prawiranegara Serang Banten yaitu dalam kategori kecemasan sedang dengan nilai rata - rata 42.80. Kecemasan yang dialami keluarga berupa perasaan tidak nyaman dengan kondisi pasien, keluarga merasa khawatir, sering merasa kelelahan dan gangguan pusing, sulit beristirahat dengan tenang, merasa sering mudah marah, jantung berdetak lebih kencang, serta tangan dan kaki sering terasa gemetar.

Hasil penelitian juga menunjukan bahawa dari seluruh responden yang ditemukan mengalami gangguan kecemasan Dari hasil wawancara beberapa responden mengungkapkan bahwa adanya rasa takut terhadap kemungkinan kematian anggota keluarga yang dirawat di ICU, serta terbatasnya menunggu pasien didalam ruang perawatan intensif menimbulkan kekhawatiran terhadap keluarga karena keluarga ingin selalu berada didekat pasien, hal diatas sejalan dengan apa yang telah dikemukakan oleh Lukmanulhakim, Suryani, Anastasia (2016), dalam penelitiannya dimana stigma masyarakat Banten sendiri yang menganggap bahwa keadaan kritis dan gawat darurat masih menjadi hal yang menakutkan, sehingga seringkali dan tidak sedikit dari keluarga adanya penolakan dengan apa yang telah terjadi pada anggota keluarganya. Kemarahan, ketakutan dan menangis merupakan bentuk dari kecemasan yang dialami keluarga saat anggota keluarganya mengalami kondisi gawat darurat, dan ekspresi yang ditimbulkan oleh seseorang dalam menanggapi kecemasan yang dialaminya dapat dipengaruhi oleh bagaimana cara hidup seseorang di masyarakat, serta budaya yang dimilikinya.

Kecemasan ini pun terjadi akibat dari beberapa hal diantaranya karena adanya peralihan tanggung jawab dan peran pengganti pasien di keluarga, sehingga peran sosial yang diperankan pasien dalam keluarga menjadi tidak ada selama pasien sakit kritis. Ketika fungsi normal tersebut tidak terpenuhi dapat menimbulkan rasa kehilangan dan memicu stressor terhadap kecemasan. selain itu rutinitas di ICU yang tidak terbiasa, kurangnya informasi yang didapatkan dari perawat atau dokter mengenai kondisi pasien, kondisi pasien saat ini, besarnya biaya yang harus dikeluarkan selama menunggu pasien, dan terbatasnya waktu menunggu pasien juga dapat menjadi faktor penyebab kecemasan yang dialami keluraga pasien kritis selama menunggu pasien (Morton, Fontaine, Hudak \& Gallo 2012). Hal yang sama dikemukakan oleh Lukmanulhakim, Firdaus (2018) dalam penelitiannya menjelaskan bahwa ketika keluarga tidak mendapatkan apa yang dibutuhkannya selama menunggu di ruang ICU, terkait informasi perkembangan penyakit anggota keluarga, dukungan mental dari staf ruang ICU serta rasa nyaman yang dirasakan selama menunggu pasien, akan berdampak terhadap peningkatan kecemasan dialami oleh keluarga, sehingga keadaan ini memungkinkan keluarga tidak dapat melakukan peraannya dengan maksimal sebagai support sistem bagi pasien,

\section{Pengaruh Yoga Pernapasan (Pranayama) terhadap Tingkat Kecemasan Keluarga Pasien di Ruang ICU}


Hasil analisis statistik menujukan terdapat perubahan skor rata - rata kecemasan sebelum dan sesudah diberikan intervensi yoga pernapasan. Selisih rata - rata kecemasan keluarga pasien kritis di ruang ICU sebelum dan setelah diberikan yoga pernapasan (pranayama) adalah 10.320 dengan standar deviasi 3.794. Hasil uji statistik $p$ value menunjukan 0.000 ( $\mathrm{P}<$ 0.005). Hasil analisis tersebut menyimpulkan bahwa terdapat pengaruh yoga pernapasan (pranayama) terhadap kecemasan keluarga pasien kritis di ruang ICU RSUD dr. Dradjat Prawiranegara Serang Banten. Hasil penelitian ini diperkuat oleh apa yang telah ditemukan oleh peneliti sebelumnya Musfirowati., Fahrudin., Nursanti (2018), yang mengidentifikasi bahwa latihan yoga dapat mempengaruhi terhadap tingkat kenyamanan, dengan latihan yoga, maka akan tercipta suasana relaksasi, akan menghilangkan suara-suara dalam pikiran sehingga tubuh akan mampu untuk melepaskan ketegangan otot. Suasana relaks akan membuat tubuh mulai santai, nafas menjadi lambat dan memberikan pengaruh positif terhadap keseluruhan sistem sirkulasi dan jantung untuk beristirahat dan mengalami proses peremajaan.

Pada penelitian ini setelah melakukan yoga pernapasan (pranayama) sebanyak 4 kali perlakuan dengan durasi 10 - 15 menit, terdapat perubahan tingkat kecemasan saat membandingkan kuesioner pre test dan post test. Pada kuesioner post test terjadi penurunan tingkat kecemasan dan respon fisiologis yang awalnya responden sering merasa jantung berdetak lebih kencang, tangan sering bergemetar, dan cepat marah menjadi lebih tenang menghadapi sesuatu yang memicu terjadinya kecemasan yaitu ketika wawancara post test yang dilakukan peneliti bahwa responden mengatakan lebih tenang dan jarang merasa gelisah dan pola tidur pun sedikit jauh lebih baik dari sebelumnya setelah diberikan yoga pernapasan (pranayama). Hal ini menunjukan ada perubahan tingkat kecemasan sebelum dan sesudah diberikan intervensi yoga pernapasan (pranayama).

Sindhu (2014) mengemukakan bahwa salah satu jenis relaksasi yang dapat menurunkan stress atau kecemasan dan belum banyak di terapkan di Indonesia adalah dengan yoga, salah satunya yoga pernapsan (pranayama). Bernapas dalam merupakan salah satu teknik dalam pengelolaan stress yang paling sederhana yang bisa dilakukan dimana saja, kapan saja, dan akan lebih efektif jika dilakukan dengan teratur (Sani, 2012).

Yoga dapat menstimulasi pengeluaran hormone endorphin. Endorphin merupakan neuro peptide yang dihasilkan oleh tubuh pada saat tubuh rileks dan tenang. Salah satu fungsi dari hormon ini adalah sebagai obat penenang alami yang dihasilkan oleh tubuh khususnya diproduksi oleh otak yang dapat menstimulus adanya rasa nyaman dan meningkatkan kadar endophrin dalam tubuh untuk mengurangi tekanan darah tinggi (Sindhu, 2014).

Ketika bernapas secara lembut dan teratur dapat melancarkan sistem peredaran darah sehingga oksigen dalam otak dapat terpenuhi dan kerja sistem otonom menjadi lebih maksimal sehingga dapat menjadikan pikiran dan tubuh menjadi lebih rileks. Yoga pernapasan (pranayama) merupkan panduan hidup dalam mengelola stress dan kecemasan yang bisa dilakukan dimana saja dan kapan saja. Tetapi, yoga masih sangat awam didengar oleh masyarakat, masih banyak orang yang beranggapan bahwa yoga hanya dilakukan oleh orang-orang tertentu.

\section{Hubungan antara Karakteristik Responden (Usia, Tingkat Pendidikan, Status Pekerjaan, Penghasilan Keluarga) Terhadap Kecemasan Keluarga Pasien Kritis di Ruang ICU}

Hasil penelitian menunjukan hasil bahwa responden yang mengalami kecemasan ringan terbanyak adalah usia dewasa awal yaitu sebanyak 11 (73.3 persen) responden, 
sedangkan yang mengalami kecemasan sedang terbanyak adalah usia dewasa awal juga yaitu sebanyak $9 \quad(90$ persen $)$ responden. Hasil penelitian ini sejalan dengan penelitian sebelumnya oleh Lukmanulhakim, Suryani \& Anastasia (2016) yang menidentifikasi bahwa responden dengan usia > 20 tahun, hampir setengah dari responden (45,9 persen) mengalami tingkat kecemasan sedang. Pada hasil uji statistik menunjukan $p$ value 0.610 , sehingga dapat disimpulkan bahwa tidak terdapat hubungan antara usia dengan kecemasan yang dialami keluarga pasien kritis di ruang ICU RSUD dr. Dradjat Prawiranegara Serang Banten.

Usia dapat mempengaruhi psikologis seseorang dan kecemasan dapat terjadi pada berbagai tingkat perkembangan usia. Usia yang tergolong dalam usia muda lebih cepat mengalami kecemasan dibandingkan dengan usia yang tergolong dalam usia dewasa, hal ini disebabkan usia dewasa memiliki mekanisme koping yang lebih optimal serta mampu berfikir secara logis (Mubarok, 2015). Hal ini menunjukan adanya ketidaksesuaian antara teori dan hasil penelitian yang dilakukan. Setiap keluarga yang berusia dewasa awal ataupun dewasa madya tetap akan mengalami kecemasan jika terdapat salah satu anggota keluarganya yang sakit dan dirawat diruang ICU. Dalam penelitian ini juga hampir seluruh responden mengungkapkan khawatir atau merasa cemas dan merasa sedih dengan kondisi keluarga yang sedang dirawat di ruang ICU.

Kecemasan dalam penelitian ini juga dapat dipengaruhi oleh faktor lain yaitu pendidikan, berdasarkan hasil penelitian menunjukan bahwa hasil bahwa responden yang mengalami kecemasan ringan terbanyak adalah responden yang berpendidikan tinggi ( $\geq$ SMA) yaitu sebanyak 14 (93.3 persen) responden. Sedangkan yang mengalami kecemasan sedang terbanyak adalah responden yang berpendidikan rendah $(\leq \mathrm{SMP})$ yaitu sebanyak 8 (80 persen) responden. Hasil uji statistik menunjukan $p$ value 0.001 , sehingga dapat disimpulkan bahwa terdapat hubungan antara tingkat pendidikan dengan kecemasan yang dialami keluarga pasien kritis di ruang ICU RSUD dr. Dradjat Prawiranegara Serang Banten.

Pendidikan pada umumnya dapat mengubah pola pikir, tingkah laku, dan pola pengambilan keputusan, semakin tinggi pendidikan seseorang maka semakin baik pola tingkah laku dan pola pengambilan keputusan (Notoatmodjo, 2010). Tingkat pendidikan dapat mempengaruhi perilaku dan sikap seseorang dalam menerima informasi sehingga tingkat pendidikan dapat mempengaruhi kecemasan yang dialami oleh seseorang. Dengan adanya dasar pendidikan yang lebih tinggi maka keluarga pasien kritis akan menacari informasi mengenai kondisi pasien yang dirawat, terap yang diberikan terhadap pasien sehingga tingkat kecemasan keluarga lebih rendah.

Status pekerjaan dan tingkat penghasilan keluarga juga dapat mempengaruhi kecemasan keluarga pasien kritis. Dalam hasil penelitian ini sebagian besar responden bekerja (60 persen) dan tingkat penghasilan 60 persen diatas UMR dengan rata - rata pekerjaan sebagai buruh pabrik, PNS, wirausaha, dan pembantu rumah tangga hal ini dapat disebabkan karena dari 25 responden 84 persen berjenis kelamin perempuan.

Berdasarkan status pekerjaan dan jumlah penghasilan, responden yang memiliki kecemasan ringan terbanyak adalah responden yang bekerja dan berpenghasilan diatas UMR, sedangkan responden yang memiliki kecemasan sedang terbanyak adalah responden yang tidak bekerja dan berpenghasilan dibawah UMR yaitu sebanyak 7 (70 persen) responden. Hasil uji statistik menunjukan p Value 0.037, sehingga dapat disimpulkan bahwa terdapat hubungan antara status pekerjaan dan penghasilan keluarga dengan kecemasan 
yang dialami keluarga pasien kritis di ruang ICU RSUD dr. Dradjat Prawiranegara Serang Banten.

Ketika pendapatan jauh lebih rendah dari pada pengeluaran maka kondisi sosial ekonomi yang tidak sehat ini dapat menimbulkan stress. Problem sosial ekonomi sangat berpengaruh terhadap jiwa seseorang dan seingkali mengakibatkan kecemasan atau stress. Pekerjaan dan tingkat penghasilan dengan kecemasan. Status sosial ekonomi dapat meningkatkan gangguan psikologis (Mubarok, 2015).

Terlepas dari apa yang dihasilkan dari penelitian ini yang menemukan bahwa adanya pengaruh yoga pranayama terhadap kecemasan keluarga pasien di ICU, akan tetapi dalam penelitian ini dapat diidentifikasi beberapa keterbatasan.. Keterbatasan dalam penelitian ini hanya melibatkan satu kelompok intervensi tanpa adanya kelompok pembanding dan ukuran sampel yang kecil.

\section{SIMPULAN DAN SARAN}

Latihan pernapasan dapat menyeimbangkan proses kerja saraf simpatis dan saraf parasimpatis sehingga dapat menyebabkan reaksi relaksasi. Yoga dapat menstimulasi pengeluaran hormone endorphin. Endorphin merupakan neuro peptide yang dihasilkan oleh tubuh pada saat tubuh rileks dan tenang. Salah satu fungsi dari hormon ini adalah sebagai obat penenang alami yang dihasilkan oleh tubuh khususnya diproduksi oleh otak yang dapat menstimulus adanya rasa nyaman. Hasil penelitian ini membuktikan bahwa pemberian intervensi yoga pernapsan (pranayama) yang merupakan salah satu dari Complementary and Alternatives Therapies (CATs) dapat mengurangi kecemasan yang dialami keluarga pasien kritis. Namun tentunya dalam mengaplikasi intervensi yoga ini diperlukan beberapa aspek yang harus diperhatikan oleh perawat diantaranya adalah aspek budaya yang dimiliki klien, serta waktu dan kondisi yang tepat untuk dapat terlaksananya intevensi yoga pranayama.

Secara praktis sekiranya hasil dari penelitian ini dapat direkomendasikan sebagai sebuah media ataupun intervensi yang diberikan kepada keluarga pasien kritis dalam pemenuhan asuhan keperawatan secara holistik khususnya oleh perawat promosi kesehatan di Rumah Sakit.

\section{DAFTAR PUSTAKA}

Dahlan, M, Sopiyudin. (2016). Besar Sampel dalam Penelitian Kedokteran dan Kesehatan. Edisi 4. Seri 2. Jakarta: Epidemiologi Indonesia.

Evans, Timothy. (2015). Guidelines for the Provision of Intensive Care Unit. The Faculty of Intensive Care Unit. Diunduh dari: http://www.ficm.ac.uk./tanggal 16 Maret 2017

Kirkwood, G., Rampes, H., Tuffrey, V., Richardson, J., Pilkington, K. (2005). Yoga for anxiety: a systematic review of the research Evidence. Journal Br J Sports Med. 39 (12), 884-89.

Lukmanulhakim., Suryani., \& Anna, Anastasia. (2016). The Relationship between communication of nurses and level of anxiety of patient's family in emergency room dr. Dradjat Prawiranegara Hospital, Serang Banten Indonesia. Int J Res Med Sci. 4.(12), 5456-5462.

Lukmanulhakim., \& Firdaus, W. (2018). Pemenuhan Kebutuhan Keluarga Pasien Kritis di ICU RSUD dr. Dradjat Prawiranegara Serang. Jurnal Ilmu Keperawatan dan Kebidanan. 9.(1), 104-110.

Morton, P.G., Fontaine, D., Hudak, C., Gallo, B., (2011). Keperawatan 
Kritis: Pendekatan Asuhan Holistik. (Vol. 1. Ed. 8.) Penerjemah: Nike Budhi Subekti, dkk. Jakarta: Buku Kedokteran EGC

Mubarak, Wahit, I., Indrawati, L., Susanto, J., (2015). Buku Ajar Ilmu Keperawatan Dasar. Buku 2. Jakarta: Salemba Medika

Musfirowati, F.,Fahrudin, A., \& Nursanti, I. (2018). The effectiveness of yogic breathing to comfort level of first trimester pregnant mothers at community health center of Kragilan district working area, Serang, Banten, Indonesia. Int J Res Med Sci. 6.(1), 51-56.

Notoatmodjo, S. (2010). Pendidikan dan Perilaku Kesehatan. Jakarta: Rineka Cipta

Nursalam. (2015). Metodologi Penelitian Ilmu Keperawatan: Pendekatan Praktis. (Ed 4). Jakarta: Salemba Medika

Oktaviana, Rina. (2014). Pengaruh Terapi Yoga Terhadap Stres pada Penderita Kanker Stadium III dan IV Di Rumah Sakit Muhammadiyah Palembang. Jurnal Ilmiah PSYCH. Vol. 8 (1). PP: 39-49

Potter, Patricia A., \& Perry, Anne Griffin. (2005). Buku Ajar Fundamental Keperawatan : Konsep, Proses, dan Praktik. (Vol. 1. Ed. 4). Penerjemah : Devi Yulianti, Monica Ester. Jakarta: Buku Kedokteran EGC.

Rachmaniah, Dini. (2012). Pengaruh Psikoedukasi terhadap Kecemasan dan Koping Orang Tua dalam Merawat Anak dengan Thalasemia Mayor di RSU Kabupaten Tangerang. Tesis. Tidak dipublikasikan. Jakarta: Universitas Indonesia.

Sani, Rachman. (2012). Yoga Untuk Kesehatan. (Ed. 1). Semarang: Dahara Prize
Sindhu, Pujiastuti. (2014). Panduan Lengkap Yoga: Untuk Hidup Sehat dan Seimbang. Bandung: Qanita.

Solehati, T., \& Kosasih, Cecep E. (2015). Konsep dan Aplikasi Relaksasi dalam Keperawatan Maternitas. Bandung: PT. Refika Aditama

Winarti, S Wahyu Eva Sri. (2014). Perbedaan Tingkat Stres pada Lansia Sebelum dan Setelah Diberikan Senam Yoga di Unit Rehabilitas Sosial Wening Wardoyo Ungaran. Naskah tidak dipublikasikan. Ilmu Keperawatan STIKes Ngudi Waluyo. Ungaran. 